\title{
Vitamin $A$ and bone formation
}

\author{
Effect of an excess of retinol on bone collagen synthesis in vitro
}

\author{
Ian DICKSON and Jill WALLS \\ Department of Medicine, University of Cambridge Clinical School, Addenbrooke's Hospital, Hills Road, \\ Cambridge CB2 2QQ, U.K.
}

(Received 13 September 1984/Accepted 19 November 1984)

\begin{abstract}
The influence of an excess of retinol on bone formation was studied by using cultures of embryonic-chick calvaria. Retinol decreased collagen synthesis in a dosedependent manner, non-collagenous protein synthesis being relatively unaffected. Collagen synthesis was significantly inhibited after $24 \mathrm{~h}$ of culture with retinol and was progressively decreased, compared with control cultures containing no retinol, as the period of culture was increased. The effect of retinol on collagen synthesis could be reversed by incubation of calvaria for further periods in retinol-free medium. Incorporation of $\left[{ }^{3} \mathrm{H}\right]$ thymidine and $\left[{ }^{3} \mathrm{H}\right]$ uridine into DNA and RNA respectively was not altered by culturing calvaria with retinol for $22 \mathrm{~h}$. These latter findings, and the selectivity for collagen synthesis, all suggested that the effect observed was not a cell-toxicity phenomenon. The effect of retinol on collagen synthesis by chick calvarial osteoblasts was probably direct and not mediated by osteoclasts, since a negligible number of the latter cells is present in chick calvaria. In cultures of neonatal murine calvaria, which contain many osteoclasts, retinol similarly inhibited synthesis of collagen, but not of non-collagenous protein; the concentrations of retinol necessary to produce the response were similar to those required to stimulate bone resorption in vitro.
\end{abstract}

Vitamin A (retinol) has a role in a number of physiological processes, including vision and reproduction, and in the maintenance of differentiated epithelia. That it has a role in the formation and metabolism of bone and cartilage is suggested by the lesions caused either by a deficiency or by an excess of the vitamin (for a review, see Barnicot \& Datta, 1972), but the mechanisms by which it acts are not well defined. Studies in vitro (Fell \& Mellanby, 1952) have demonstrated that retinol can stimulate resorption of bone and cartilage. Subsequent work on the mechanisms of cartilage resorption has shown the effects of retinol on lysosomal enzymes (Lucy et al., 1961). Synthesis of cartilage matrix can also be influenced, since retinol can selectively inhibit synthesis of glycosaminoglycans by chondrocytes in culture (Solursh

Abbreviations used: $1,25(\mathrm{OH})_{2} \mathrm{D}_{3}, 1,25$-dihydroxycholecalciferol (' 1,25 -dihydroxyvitamin $\left.\mathrm{D}_{3}{ }^{\prime}\right) ; 25(\mathrm{OH}) \mathrm{D}_{3}$, 25-hydroxycholecalciferol.
\& Meier, 1973). Although its effects on bone resorption have been studied (Raisz, 1965a,b; Reynolds, 1968), it has not been demonstrated that retinol can directly affect bone-forming cells.

The ability of retinol to stimulate bone resorption is shared with a number of agents, including $1,25(\mathrm{OH})_{2} \mathrm{D}_{3}$ and parathyroid hormone. Some bone-resorbing agents, including $1,25(\mathrm{OH})_{2} \mathrm{D}_{3}$ (Raisz et al., 1978) and parathyroid hormone (Dietrich et al., 1976), can also act directly on boneforming cells to inhibit synthesis of collagen. It therefore seemed logical to determine whether retinol had a similar effect on bone collagen synthesis. Two systems have been used to study retinol action: cultures of embryonic-chick calvaria, which, - since they contain negligible numbers of osteoclasts (Turner et al., 1980; Nijweide et al., 1981), provide a convenient means of studying bone forming cells, and secondly, cultures of neonatal murine calvaria, which contain both bone-forming and bone-resorbing cells. 


\section{Materials and methods}

\section{Materials}

Retinol and other biochemicals were obtained from Sigma. A solution of retinol $(10 \mathrm{mg} / \mathrm{ml})$ in ethanol was freshly prepared before each experiment and portions diluted to the appropriate concentration with culture medium. Radiochemicals were obtained from Amersham International. Chemicals were of A.R. grade or the best otherwise available.

\section{Chick calvarial culture}

Fertile pathogen-free eggs of a White Leghorn strain, incubated for 16 days, were obtained from the University School of Veterinary Medicine. The skin of the head of the embryo was cut back and the layer of fascia beneath it was cut along the orbit to expose the calvarium, which was removed as two halves. The calvaria were placed immediately in Hank's balanced salt solution or a lowbicarbonate modified form of the BGJ (Biggers, Gwatkin and Judah) medium (Biggers et al., 1961). This modified medium was similar to that of Reynolds (1976), except for the concentration of $\mathrm{NaHCO}_{3}$, and differed from the $\mathrm{BGJ}_{\mathrm{b}}$ of Biggers et al. (1961) in respect of the following components (concentrations, in $\mathrm{mg} / \mathrm{l}$, are given in parentheses): $\mathrm{KCl}$ (350); $\mathrm{KH}_{2} \mathrm{PO}_{4}$ (35); $\mathrm{NaCl}(6200)$; sodium acetate (83); $\mathrm{NaHCO}_{3}$ (500); $\mathrm{NaH}_{2} \mathrm{PO}_{4}$ (140); myo-inositol (1); calcium pantothenate (0.5); thiamin hydrochloride (2); ascorbic acid (150). The prefrontal bone and a ridge of the frontal bone adjacent to the eye, was removed from the halfcalvaria with ophthalmic surgical scissors (J. Weiss and Sons, London W1H 0DN, U.K.) and discarded. The frontal bones were cultured with $1 \mathrm{ml}$ of medium on grids of stainless-steel mesh (Ref. 978 MM; Expamet, Hartlepool, Cleveland, U.K.) in Petri dishes containing compartments $2 \mathrm{~cm}$ square. The modified $\mathrm{BGJ}_{\mathrm{b}}$ medium described above was used, but the concentration of $\mathrm{NaHCO}_{3}$ was raised to $2200 \mathrm{mg} / 1$ and bovine serum albumin $(5 \mathrm{mg} / \mathrm{ml}$; Sigma) was added. Incubation was at $37^{\circ} \mathrm{C}$ with a gas phase of $\mathrm{CO}_{2}$ /air (1:19).

\section{Mouse calvarial culture}

For studies of collagen synthesis, mice of T.O. strain (obtained from A. Tuck and Sons, Battlesbridge, Wickford, Essex, U.K.) and aged 4 days were killed with chloroform and dipped briefly in $70 \%$ (v/v) ethanol. The skin of the head was removed to expose the calvarium, which was dissected out and placed in low-bicarbonate dissecting medium, as used for chick calvaria. With the aid of a binocular dissecting microscope any adhering brain tissue was carefully removed.
The calvarium was cut in half along the median suture and bone from adjacent areas was cut away with ophthalmic surgical scissors along the suture lines to leave the frontal and parietal bones, care being taken to keep the periosteum intact. The half-calvaria were cultured on steel grids with $1 \mathrm{ml}$ of medium under conditions identical with those used for chick calvarial cultures.

\section{Mouse calvarial resorption assay}

The procedure used was essentially that of Reynolds (1976), but the medium used for culture contained bovine serum albumin $(5 \mathrm{mg} / \mathrm{ml})$ rather than serum. Mice less than $24 \mathrm{~h}$ old were injected subcutaneously with ${ }^{45} \mathrm{CaCl}_{2}(1 \mu \mathrm{Ci}$ in $0.05 \mathrm{ml}$ of $0.15 \mathrm{M}-\mathrm{NaCl}$ ). After 4 days, the mice were killed; calvaria were dissected and half-calvaria cultured on grids with $1 \mathrm{ml}$ of medium as described above. After pre-incubation for $24 \mathrm{~h}$ the medium for one half-calvarium was replaced with $1 \mathrm{ml}$ of control medium and that of the paired half-calvarium was replaced with medium containing retinol. After incubation for a further $48 \mathrm{~h}$, the tissue was removed, blotted with filter paper and digested with $0.2 \mathrm{ml}$ of formic acid at $60^{\circ} \mathrm{C}$ for $2 \mathrm{~h}$ in a scintillation mini-vial. To the cooled digest was added $3 \mathrm{ml}$ of scintillation fluid (Picofluor 15; Packard) and the sample counted for radioactivity in a liquid-scintillation counter. A portion of the $48 \mathrm{~h}$ culture medium $(0.5 \mathrm{ml})$ was counted for radioactivity after mixing with $3 \mathrm{ml}$ of Picofluor 30 scintillation fluid. The amount of resorption was calculated as $\left({ }^{45} \mathrm{Ca}\right.$ in medium $) /\left({ }^{45} \mathrm{Ca}\right.$ in medium $+{ }^{45} \mathrm{Ca}$ remaining in calvarium) and expressed as a percentage.

\section{Estimation of collagen and non-collagenous protein synthesis}

Calvaria were labelled by the addition to the culture medium of $0.05 \mathrm{ml}$ of medium containing $5 \mu \mathrm{Ci}$ of $\mathrm{L}-\left[5-{ }^{3} \mathrm{H}\right]$ proline and $50 \mu \mathrm{g}$ of ascorbic acid, $4 \mathrm{~h}$ before the end of the culture period. The calvaria were then extracted three times with $5 \%$ (w/v) trichloroacetic acid containing $10 \mathrm{~mm}$-proline at $0-5^{\circ} \mathrm{C}$, three times with acetone, twice with diethyl ether, air-dried and weighed.

The bones were homogenized in $0.5 \mathrm{M}$-acetic acid in glass homogenizers. Portions of the homogenates were taken for determination of collagenase-digestible (CDP) and collagenase-nondigestible (NCP) protein by the procedure of Peterkofsky \& Diegelmann (1971). Bacterial collagenase (CLSPA grade, Worthington Co.) was further purified before use by DEAE-cellulose and Sephadex G-200 column chromatography (LeeOwn \& Anderson, 1975); the non-specific proteinase activity of the final product was $1.4 \%$ of that of the CLSPA-grade starting material, with, as 
substrate, chick-embryo extract labelled with $\left[{ }^{3} \mathrm{H}\right]$ tryptophan. Blanks without enzyme were included for each sample. In calculations of percentage collagen synthesis a factor of 5.4 was used to correct for the excess of proline in collagen compared with non-collagenous protein (Peterkofsky, 1972).

\section{DNA and RNA synthesis}

Incorporation of labelled thymidine into DNA and of uridine into RNA was done by procedures similar to those described by Canalis et al. (1977). For thymidine incorporation, calvaria were cultured for $18 \mathrm{~h}$ in medium containing bovine serum albumin $(5 \mathrm{mg} / \mathrm{ml})$ and thymidine $(100 \mu \mathrm{M})$. $\left[{ }^{3} \mathrm{H}\right]$ Thymidine was added to give a final concentration of $10 \mu \mathrm{Ci} / \mathrm{ml}$, and incubation continued for a further $1 \mathrm{~h}$. The calvaria were dipped briefly in $0.15 \mathrm{M}-\mathrm{NaCl}$ and lightly blotted with filter paper. The calvaria were homogenized in $0.15 \mathrm{M}-\mathrm{NaCl}$, the final volume being adjusted to $1 \mathrm{ml}$, and $2 \mathrm{ml}$ of cold $10 \%(\mathrm{w} / \mathrm{v})$ trichloroacetic acid was added; operations were performed at $0-5^{\circ} \mathrm{C}$. After $10 \mathrm{~min}$ the solution was centrifuged $(1200 \mathrm{~g} ; 5 \mathrm{~min})$ and the residue extracted twice more with $1 \mathrm{ml}$ of $10 \%$ trichloroacetic acid. Portions of the three supernatant solutions were taken for liquid-scintillation counting. The total amount of ${ }^{3} \mathrm{H}$ radioactivity extracted with cold trichloroacetic acid was termed the 'trichloroacetic acid-extractable pool'. The residue was extracted at $90^{\circ} \mathrm{C}$ for $15 \mathrm{~min}$ with $2 \mathrm{ml}$ of $5 \%$ trichloroacetic acid and a portion of this extract was taken for radioactivity counting. ${ }^{3} \mathbf{H}$ radioactivity extracted with hot trichloroacetic acid in this manner was termed the 'DNA fraction'.

The procedure for uridine incorporation was similar to that described for thymidine, except that uridine $(100 \mu \mathrm{M})$ was added to the medium instead of thymidine and labelling was with $\left[{ }^{3} \mathrm{H}\right]$ uridine $(10 \mu \mathrm{Ci} / \mathrm{ml})$. After the three extractions with cold $10 \%$ trichloroacetic acid the residue was extracted with $1 \mathrm{M}-\mathrm{KOH}\left(1 \mathrm{ml}\right.$ for $18 \mathrm{~h}$ at $\left.37^{\circ} \mathrm{C}\right)$. The solution was cooled and $0.1 \mathrm{ml}$ of $10 \mathrm{M}-\mathrm{HCl}$ and $0.4 \mathrm{ml}$ of $30 \%(w / v)$ trichloroacetic acid added. After $10 \mathrm{~min}$ the mixture was centrifuged $(1200 \mathrm{~g} ; 5 \mathrm{~min})$ and a portion of the supernatant solution, which was termed the 'RNA fraction', was taken for liquidscintillation counting. The total amount of ${ }^{3} \mathrm{H}$ radioactivity solubilized with the three cold trichloroacetic acid extractions was termed the 'trichloroacetic acid-extractable pool'.

\section{Results}

Collagen synthesis by chick calvaria, as estimated by incorporation of $\left[{ }^{3} \mathrm{H}\right]$ proline into collagenase-digestible protein, was selectively inhibited by retinol (Fig. 1), although non-collagenous protein synthesis was significantly less than controls at higher concentrations of retinol. From the data shown, we have estimated that collagen synthesis, expressed as a percentage of total protein synthesis, was $38 \%$ in control cultures and this proportion decreased progressively, with increasing concentration of retinol, to $15 \%$ at $20 \mu \mathrm{g}$ of $\mathrm{retinol} / \mathrm{ml}$. At lower $(0.001-1 \mu \mathrm{g} / \mathrm{ml})$ concentrations of retinol, synthesis of collagen and noncollagenous protein was not significantly different from controls (results not shown).

An effect of retinol on collagen synthesis could be observed after $24 \mathrm{~h}$ of culture (Fig. 2), and this increased with time in culture; non-collagenous protein synthesis was only inhibited after culture for 6 days.

The effect of retinol on collagen synthesis did not appear to be secondary to changes in cell proliferation, since incorporation of $\left[{ }^{3} \mathrm{H}\right]$ thymidine into calvaria or the DNA fraction was not affected by this compound (Table 1). Incorporation of $\left[{ }^{3} \mathrm{H}\right]$ uridine into calvaria or the RNA fraction was similarly unaffected by treatment with retinol for $22 \mathrm{~h}$.

The inhibitory effects on collagen synthesis produced by incubation of calvaria with retinol for $24 \mathrm{~h}$ could be reversed by a further incubation with retinol-free medium (Table 2). However, the effect produced by prolonged incubation ( $48 \mathrm{~h}$ ) with $10 \mu \mathrm{g}$ of retinol $/ \mathrm{ml}$ was not fully reversible.

Some experiments were carried out with cultures of neonatal murine calvaria to establish whether or not the effect of retinol was specific to chick

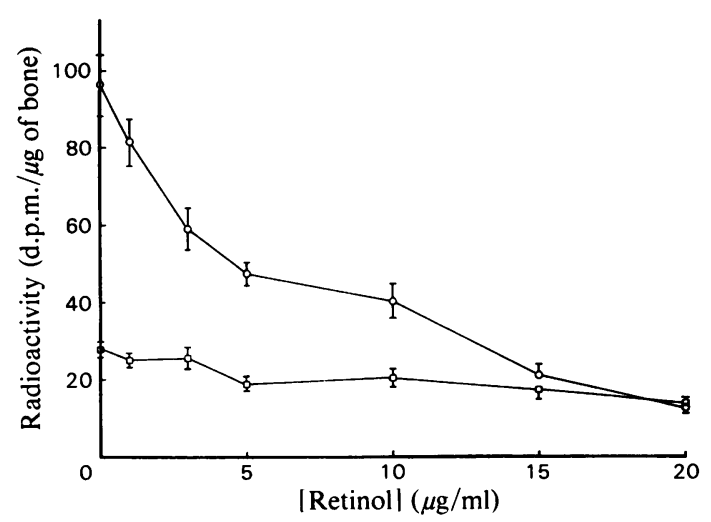

Fig. 1. Influence of various retinol concentrations on $\left[{ }^{3} \mathrm{H}\right]$ proline incorporation into collagenase-digestible protein and non-collagen protein in embryonic-chick calvaria Results are for incorporation into collagenasedigestible protein $(O)$ and non-collagen protein $(\square)$ and are the mean \pm S.E.M. of five observations in each case. Incubation was for $48 \mathrm{~h}$. 
Table 1. Effect of retinol on uptake and incorporation of $(a)\left[{ }^{3} H\right]$ thymidine and $(b)\left[{ }^{3} \mathrm{H}\right]$ uridine into embryonic-chick calvaria Values are means \pm S.E.M. $(n=5)$ for bones incubated for $22 \mathrm{~h}$ in the presence or absence of retinol $(10 \mu \mathrm{g} / \mathrm{ml})$ and treated for the last $60 \mathrm{~min}$ with $\left[{ }^{3} \mathrm{H}\right]$ thymidine or $\left[{ }^{3} \mathrm{H}\right]$ uridine. For details, see the Materials and methods section. Abbreviation used: TCA, trichloroacetic acid.

Radioactivity (d.p.m./bone)

\begin{tabular}{lcc} 
(a) Incorporation of $\left[{ }^{3} \mathrm{H}\right]$ thymidine & TCA-extractable pool & DNA fraction \\
\hline Control & $78104 \pm 8087$ & $662 \pm 157$ \\
Retinol & $76863 \pm 6970$ & $734 \pm 154$ \\
& Radioactivity (d.p.m./bone) \\
\cline { 2 - 3 } (b) Incorporation of $\left[{ }^{3} \mathrm{H}\right]$ uridine & TCA-extractable pool & RNA fraction \\
\hline Control & $151864 \pm 13889$ & $7495 \pm 659$ \\
Retinol & $146111 \pm 4580$ & $7164 \pm 261$
\end{tabular}

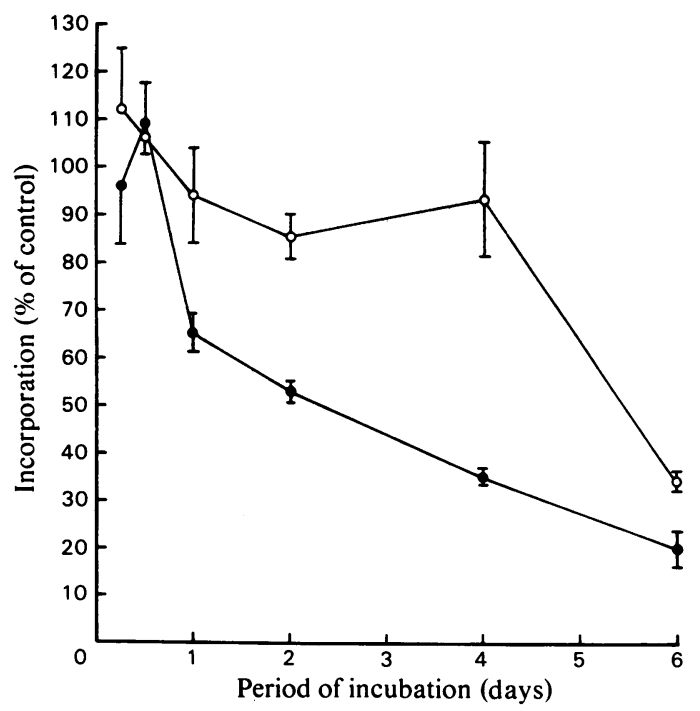

Fig. 2. Temporal effect of retinol on $\left[{ }^{3} \mathrm{H}\right]$ proline incorporation into collagenase-digestible protein and non-collagen protein in embryonic-chick calvaria

Results are for incorporation into collagenasedigestible protein $(O)$ and non-collagen protein $(O)$ and are means \pm S.E.M. for five observations in each case expressed as a percentage of corresponding values for control cultures incubated for the same period in retinol-free medium, i.e. $100 \times($ d.p.m. $/ \mu \mathrm{g}$ of test bone)/(d.p.m./ $\mu \mathrm{g}$ of control bone). The concentration of retinol used was $10 \mu \mathrm{g} / \mathrm{ml}$.

calvarial cultures and to enable a comparison to be made with effects on bone resorption. Retinol inhibited collagen synthesis by murine calvaria (Fig. 3), but non-collagenous-protein synthesis remained relatively unaffected, although values of the latter differed significantly from controls at higher concentrations of retinol. The concentra-

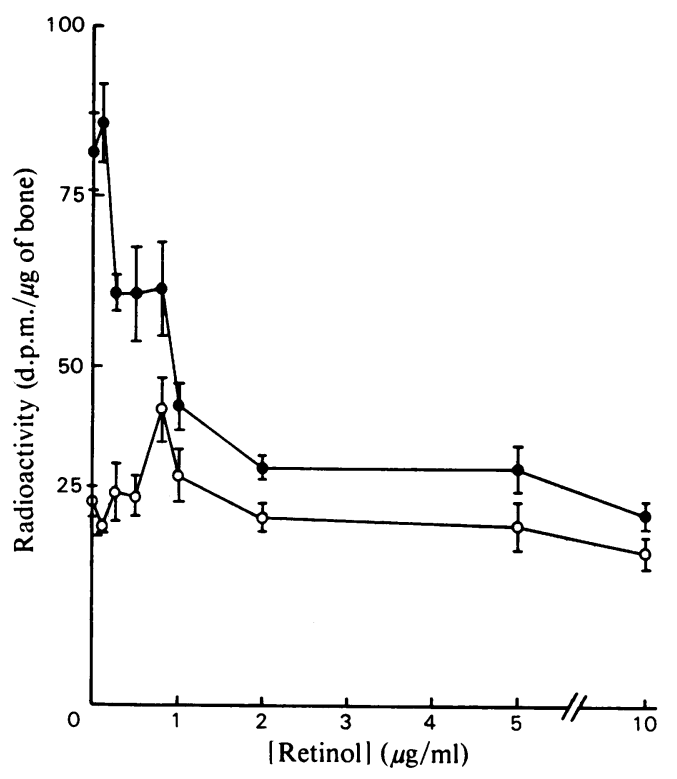

Fig. 3. Influence of various retinol concentrations on $\left[{ }^{3} \mathrm{H}\right]$ proline incorporation into collagenase-digestible protein and non-collagen protein in neonatal murine calcaria Results are for incorporation into collagenase digestible protein $(O)$ and non-collagen protein $(O)$ and are means \pm S.E.M. for five observations in each case. Incubation was for $48 \mathrm{~h}$.

tion of retinol necessary to inhibit collagen synthesis was similar to that required to stimulate bone resorption (Fig. 4).

\section{Discussion}

The relationship between retinol and retinoids and the resorption of cartilage and bone have been studied by many investigators; most of these 
Table 2. Reversibility of retinol effect on collagen synthesis by embryonic-chick calvaria Bones were incubated in $1 \mathrm{ml}$ of medium containing retinol for the period stated. The medium was then withdrawn and replaced with $1 \mathrm{ml}$ of retinol-free medium to wash the calvaria and dish. The latter medium was replaced with a further $1 \mathrm{ml}$ of retinol-free medium and incubation was continued for the stated period. In experiments involving a 3day incubation in retinol-free medium, the medium was changed after 1 day. Towards the end of the culture period, bones were labelled with $\left[{ }^{3} \mathrm{H}\right.$ ]proline and incorporation of the isotope into collagenase digestible protein (CDP) measured as described in the text. The results of four separate experiments are shown. Values are of ${ }^{3} \mathrm{H}$ incorporation into collagenase-digestible protein (CDP) expressed as a percentage of incorporation into control bones which had been cultured for a similar total period but in retinol-free medium, i.e. $100 \times($ d.p.m. $/ \mu \mathrm{g}$ of test bone $) /(\mathrm{d} . \mathrm{p} . \mathrm{m} . / \mu \mathrm{g}$ of control bone); values are means \pm S.E.M. $(n=5)$.

\begin{tabular}{ccccc} 
Exp. no. & $\begin{array}{c}\text { Period in } \\
(\mu \mathrm{R} / \mathrm{ml})\end{array}$ & $\begin{array}{c}\text { Period in } \\
\text { retinol-free } \\
\text { (days) }\end{array}$ & $\begin{array}{c}\text { medium } \\
\text { (days) }\end{array}$ & $\begin{array}{c}\text { CDP } \\
(\% \text { of control })\end{array}$ \\
\hline 1 & 5 & 1 & 3 & $101 \pm 5$ \\
2 & 5 & 2 & 2 & $112 \pm 19$ \\
3 & 10 & 1 & 3 & $91 \pm 10$ \\
4 & 10 & 2 & 2 & $60 \pm 4$
\end{tabular}

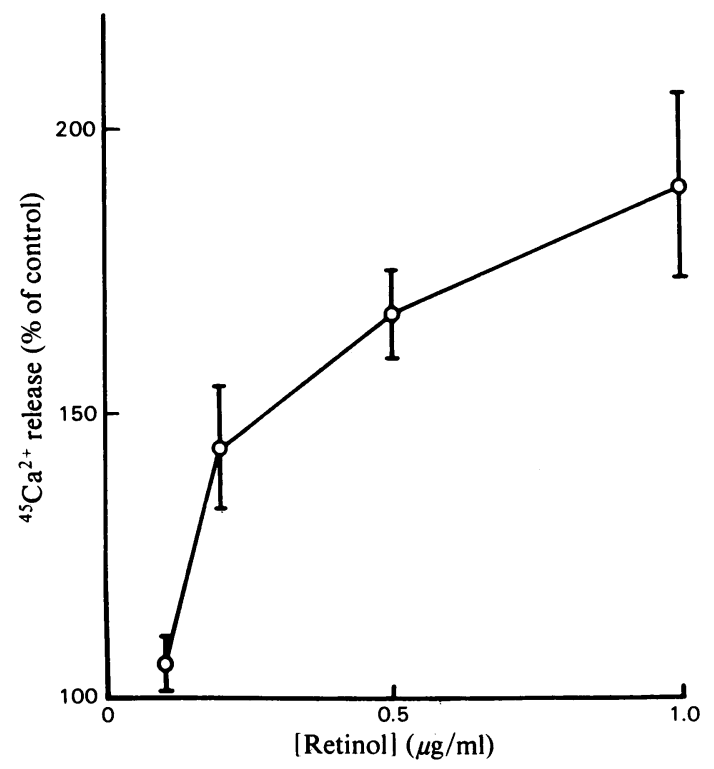

Fig. 4. Effect of various retinol concentrations on release of ${ }^{45} \mathrm{Ca}^{2+}$ into medium by neonatal murine calvaria The proportion of total ${ }^{45} \mathrm{Ca}^{2+}$ in a half-calvarium released into the medium during incubation with retinol-containing medium is expressed as a percentage of the corresponding value for the paired halfcalvarium incubated in control medium. Values shown are means \pm S.E.M. for five observations. For full details, see the Materials and methods section.

studies have concerned effects on resorption rather than formation. Cartilage resorption by retinol can be related to the release of lysosomal enzymes (Lucy et al., 1961; Fell \& Dingle, 1963). This is supported by evidence that the retinol-induced loss of polysaccharide from cartilage matrix can be partially prevented by a proteinase inhibitor or by a lysosomal-membrane stabilizer (Brighton \& Schaffzin, 1970) or by specific antiserum to the lysosome-derived enzyme cathepsin D (Weston et al., 1969). Retinoid-induced resorption may require new protein synthesis, since the stimulation by retinoic acid of cartilage resorption (Kistler, 1978) or by retinol of bone resorption (Raisz, $1965 b$ ) can be prevented by inhibitors of RNA and protein synthesis.

The observations in our study of bone seem consistent with numerous earlier reports that retinoids can inhibit synthesis by chondrocytes of extracellular matrix macromolecules. Solursh \& Meier (1973) reported that vitamin A selectively inhibited glycosaminoglycan synthesis by cell cultures of chick-embryo sternal chondrocytes; incorporation of leucine into acid-insoluble material was unaltered, as was collagen synthesis, although the latter was decreased at a later stage of culture. There are other reports (Vasan \& Lash, 1975) that retinol inhibits synthesis of these carbohydrates and that it can alter the size of proteoglycan synthesized (Vasan, 1981). Kistler (1982) observed that retinoic acid caused decreased incorporation of leucine or mannose into the trichloroacetic acid-insoluble material of the cartilagenous epiphyses of foetal rat bones in organ culture, although electrophoretic studies showed that the synthesis of some specific proteins was unaffected. The ability of retinol or its metabolite retinoic acid to inhibit synthesis of extracellularmatrix macromolecules by chondrocytes thus seems generally consistent with its effects on bone collagen synthesis as seen in the present study.

Our observations are unlikely to be a reflection of a toxic effect of retinol on bone-forming cells. If that were so, protein synthesis generally would be 
depressed, whereas the effect is selective for collagen synthesis. Also, this inhibition of collagen synthesis is reversible, which would be unlikely if it resulted from toxicity. The fact that incorporation of uridine and thymidine into RNA and DNA respectively is unaltered by retinol provides additional strong support for the view that it is producing a specific response in bone cells.

Retinol probably acts directly on bone-forming cells to inhibit collagen synthesis rather than that the effect is mediated by the release of an inhibitor by osteoclasts. The fact that inhibition of collagen synthesis occurs rapidly and that it occurs in chick calvaria, which contain a negligible number of osteoclasts (Turner et al., 1980; Nijweide et al., 1981) seems inconsistent with an osteoclast-mediated effect. It is possible that measures of retinolinduced bone resorption in vitro, i.e. net loss of mineral or matrix components from the tissue to the medium, may to some extent reflect decreased synthesis coupled with normal turnover rather than solely a stimulation of resorption. It should be noted that retinol was found to be able to inhibit collagen synthesis by murine calvaria at approximately one-tenth of the concentration required for chick calvaria. The former are similarly more sensitive than chick calvaria with respect to the inhibitory effect of $1,25(\mathrm{OH})_{2} \mathrm{D}_{3}$ on collagen synthesis (I. Dickson \& J. Walls, unpublished work). Although this increased sensitivity of murine calvaria probably results from differences in the properties of osteoblasts from the two species, the possibility that the presence of osteoclasts has some potentiating effect cannot entirely be discounted.

It is worth comparing the action of retinol on bone to that of parathyroid hormone and $1,25(\mathrm{OH})_{2} \mathrm{D}_{3}$. Parathyroid hormone acts via a plasma-membrane receptor, leading to activation of a cyclic AMP-dependent protein kinase (Partridge et al., 1981). In contrast, $1,25(\mathrm{OH})_{2} \mathrm{D}_{3}$ appears to act in the manner of many steroid hormones, by binding to a cytosolic receptor (Kream et al., 1977). Despite this difference, both hormones alter collagen synthesis in a similar manner, at a pretranslational level, by altering the level of functional procollagen mRNA (Kream et al., 1980; Rowe \& Kream, 1982). Retinol and retinoids may be able to interact with the cell by more than one mechanism. There is evidence that retinol can interact directly with lysosomes (Goodman et al., 1974) and other evidence that retinoids can act on the plasma membrane and influence membrane glycoprotein synthesis (DeLuca, 1977). Retinol and other retinoids may also be able to exert their action through the nucleus; as for steroid hormones, there are intracellular binding proteins for retinol and retinoic acid (Chytil \&
Ong, 1979) that mediate binding to nuclear chromatin, although the interaction of retinol with the latter may differ from that of steroid hormones (Liau et al., 1981).

There is also evidence, from studies of other tissues, of interrelationships between retinol, calcium metabolism, parathyroid hormone and $1,25(\mathrm{OH})_{2} \mathrm{D}_{3}$. An excess of retinol can stimulate the release of parathyroid hormone by the parathyroid gland (Chertow et al., 1977), and both retinol and retinoic acid can produce a dose-related stimulation of $25(\mathrm{OH}) \mathrm{D}_{3}$ 1-hydroxylase activity by primary cultures of chick kidney cells (Trechsel \& Fleisch, 1981). Bone collagen synthesis in vitro appears to be sensitive to changes in $\mathrm{Ca}^{2+}$ concentration; it can be inhibited by decreasing $\mathrm{Ca}^{2+}$ in the medium or in the presence of $\mathrm{a} \mathrm{Ca}^{2+}$ ionophore (Dietrich \& Paddock, 1979) or a $\mathrm{Ca}^{2+}$ antagonist (Dietrich \& Duffield, 1979), and several other factors that modify collagen synthesis probably act on bone cells by $\mathrm{Ca}^{2+}$-dependent mechanisms [for a review of factors that affect bone formation, see Raisz \& Kream (1983)]. It is thus possible that the effect of retinol on bone collagen synthesis may involve a $\mathrm{Ca}^{2+}$-mediated stage.

We thank the Medical Research Council for financial support and Mrs. Sandra Webb for her skilled assistance. We also thank Dr. Peter Royce for his help with the collagenase purification and for the gift of $\left[{ }^{3} \mathrm{H}\right]$ tryptophan-labelled substrate, Mr. Gary Dew for advice about the bone-resorption assay, and Dr. David Fraser for reading the manuscript.

\section{References}

Barnicot, N. A. \& Datta, S. P. (1972) in The Biochemistry and Physiology of Bone (Bourne, G. H., ed.), vol. 2, pp. 197-229, Academic Press, London and New York

Biggers, J. D., Gwatkin, R. B. L. \& Heyner, S. (1961) Exp. Cell Res. 25, 41-58

Brighton, C. T. \& Schaffzin, E. A. (1970) Calcif. Tissue Res. 6, 151-161

Chertow, B. S., Williams, G. A., Norris, R. M., Baker, G. R. \& Hargis, G. K. (1977) Eur. J. Clin. Invest. 7, 307-314

Canalis, E. M., Dietrich, J. W., Maina, D. M. \& Raisz, L. G. (1977) Endocrinology (Baltimore) 100, 668-674

Chytil, F. \& Ong, D. E. (1979) Fed. Proc. Fed. Am. Soc. Exp. Biol. 38, 2510-2514

DeLuca, L. M. (1977) in Vitamins and Hormones (Munson, P. L. Glover, J., Diczfalusy, E. \& Olson, R. E., eds.), vol. 35, pp. 1-57, Academic Press, New York, San Francisco and London

Dietrich, J. W. \& Duffield, R. (1979) Endocrinology (Baltimore) 105, 1168-1172

Dietrich, J. W. \& Paddock, D. N. (1979) Endocrinology (Baltimore) 104, 493-499

Dietrich, J. W., Canalis, E. M., Maina, D. M. \& Raisz, L. G. (1976) Endocrinology (Baltimore) 98, 943-949 
Fell, H. B. \& Dingle, J. T. (1963) Biochem. J. 87, 403-408

Fell, H. B. \& Mellanby, E. (1952) J. Physiol. (London) 116, 320-349

Goodman, D. S., Smith, J. E., Hembry, R. M. \& Dingle, J. T. (1974) J. Lipid Res. 15, 406-414

Kistler, A. (1978) Experientia 34, 1159-1161

Kistler, A. (1982) Differentiation 21, 168-174

Kream, B. E., Jose, M., Yamada, S. \& DeLuca, H. F. (1977) Science 197, 1086-1088

Kream, B. E., Rowe, D. W., Gworek, S. C. \& Raisz, L. G. (1980) Proc. Natl. Acad. Sci. U.S.A. 77, 56545658

Lee-Own, V. \& Anderson, J. C. (1975) Prep. Biochem. 5, 229-245

Liau, G., Ong, D. E. \& Chytil, F. (1981) J. Cell. Biol. 91, 63-68

Lucy, J. A., Dingle, J. T. \& Fell, H. B. (1961) Biochem. J. 79, 500-508

Nijweide, P. J., van der Plas, A. \& Scherft, J. P. (1981) Calcif. Tissue Int. 33, 529-540

Partridge, N. C., Kemp, B. E., Veroni, M. C. \& Martin, T. J. (1981) Endocrinology (Baltimore) 108, 220-225

Peterkofsky, B. (1972) Arch. Biochem. Biophys. 152, 318328

Peterkofsky, B. \& Diegelmann, R. (1971) Biochemistry 10, 988-994

Raisz, L. G. (1965a) J. Clin. Invest. 44, 103-116
Raisz, L. G. (1965b) Proc. Soc. Exp. Biol. Med. 119, 614617

Raisz, L. G. \& Kream, B. E. (1983) N. Engl. J. Med. 309, 29-35; 83-89

Raisz, L. G., Maina, D. M., Gworek, S. C., Dietrich, J. W. \& Canalis, E. M. (1978) Endocrinology (Baltimore) 102, 731-735

Reynolds, J. J. (1968) Proc. R. Soc. London Ser. B 170, 61-69

Reynolds, J. J. (1976) in Organ Culture in Biomedical Research (Balls, M. \& Monnickendam, M. A., eds.), pp. 355-366, Cambridge University Press, Cambridge

Rowe, D. W. \& Kream, B. E. (1982) J. Biol. Chem. 257, 8009-8015

Solursh, M. \& Meier, S. (1973) Calcif. Tissue Res. 13, $131-142$

Trechsel, U. \& Fleisch, H. (1981) FEBS Lett. 135, $115-$ 118

Turner, R. T., Puzas, J. E., Forte, M. D., Lester, G. E., Gray, T. K., Howard, G. A. \& Baylink, D. J. (1980) Proc. Natl. Acad. Sci. U.S.A. 77, 5720-5724

Vasan, N. S. (1981) J. Embryol. Exp. Morphol. 63, 181191

Vasan, N. S. \& Lash, J. W. (1975) Calcif. Tissue Res. 19, 99-107

Weston, P. D., Barrett, A. J. \& Dingle, J. T. (1969) Nature (London) 222, 285-286 